\title{
Sistem Data Logger Lima Channel Input untuk Sensor Navigasi Kapal Maritim
}

\section{Five Inputs Channel Data Logger System for Maritime Ship Navigation Sensors}

\author{
Octa Heriana $^{\mathrm{a}, *}$ dan Heru Rahmat Mulyadi ${ }^{\mathrm{b}}$ \\ ${ }^{a}$ Pusat Penelitian Elektronika dan Telekomunikasi, Lembaga Ilmu Pengetahuan Indonesia. \\ Komp LIPI Gd 20, Jl Sangkuriang 21/54D, Bandung 40135, Indonesia \\ ${ }^{b}$ Jurusan Teknik Elektro, Fakultas Sains dan Teknologi, \\ Universitas Islam Negeri Sunan Gunung Djati, Bandung
}

\begin{abstract}
Abstrak
Sistem data logger telah banyak dikembangkan untuk berbagai keperluan perolehan data untuk melakukan proses monitoring dan akuisisi data. Penelitian ini adalah aplikasi data logger untuk pemrosesan lima data dari sensor-sensor navigasi pada suatu kapal maritim. Peralatan sensor navigasi kapal maritim di Indonesia sudah mendukung protokol komunikasi secara digital yang mengacu pada format standar komunikasi sensor kemaritiman National Marine Electronics Association (NMEA). Terdapat lima sensor navigasi yang digunakan sebagai standar minimal yang mendukung kapal maritim untuk dapat beroperasi di lautan, yaitu; sensor GPS, Gyrocompass, Echosounder, Weather dan Velocity. Penelitian ini mencoba untuk menampung lima buah data sensor yang berbeda, kemudian menggabungkannya dalam suatu variabel dengan susunan format data yang baru sebagai data output. Data output kemudian dikirimkan pada PC untuk diterjemahkan melalui software, dan data setiap sensor ditampilkan pada software aplikasi tersebut. Sistem ini dibangun dengan Arduino ATMega328 sebagai prosesor. Pengkondisi data input dibuat dengan kombinasi rangkaian IC 74LS08 dan IC 74LS32. Hasil penelitian ini adalah prototipe data logger yang menangani sejumlah lima data sensor dengan format standar NMEA dan satu output data sensor-sensor yang telah disusun dengan format tertentu, dengan tingkat akurasi saat pengiriman data sebesar $100 \%$ dan ekstraksi data pada software aplikasi display sebesar; 96\% untuk sensor GPS, 97\% untuk Gyro, 98\% untuk Echosounder, 97\% untuk Weather, dan 98\% untuk sensor Velocity.
\end{abstract}

Kata kunci: data logger, sensor, navigasi, NMEA.

Abstract

Data logger systems have been developed for many various data mining requirements to do monitoring and data acquition processes. This research is the application of data logger for processing five navigation sensors data in the maritime ship. Maritime ship navigation sensors equipments in Indonesia have already supported by the digital communication protocol that refers to a maritime communication sensor format standard known as National Marine Electronics Association (NMEA). There are five navigation sensors which are used as a minimum standard that supports maritime vessels to operate in the oceans, namely; GPS, Gyrocompass, Echosounder, Weather and Velocity Sensors. This study tries to accommodate five different pieces of sensor data, then combine them into a variable with a new arrangement of data formats as the output data. Output data is then sent to the PC to be translated through software, and the data of each sensor is displayed on the application software. The system is built with Arduino ATmega328 as the processor. The data input conditioning is made by combining $74 L S 32$ and $74 L S 08$ circuit. The result of this study is a data logger prototype that handles five NMEA format standard sensors data and one sensors output data which have been prepared with a specific format, with the level of accuracy when sending data is $100 \%$, and the data extraction of the application software display is; 96\% for the GPS sensor, 97\% for Gyro sensor, 98\% for the echosounder, 97\% for Weather sensor, and 98\% for Velocity sensors.

Keywords: data logger, sensor, navigation, NMEA.

\section{Pendahuluan}

Standar komunikasi digital untuk sensor-sensor navigasi pada sebuah kapal maritim sangat bermanfaat untuk keseragaman prosedur interfacing dengan peralatan-peralatan elektronik pendukung navigasi dalam kapal, seperti misalnya; Electronic Chart Display (ECDIS), radar, dan interface pemandu komando

\footnotetext{
* Corresponding Author.

Email: octa.heriana@lipi.go.id

Received: December 3, 2014; Revised: December 12, 2014

Accepted: December 24, 2014

Published: December 30, 2014

(C) 2014 PPET - LIPI

doi : 10.14203/jet.v14.61-66
}

navigasi lainnya. Format standar komunikasi data sensor-sensor navigasi telah diatur secara internasional melalui suatu badan asosiasi yang bernama National Marine Electronics Association (NMEA) [1].

Format standar komunikasi data digital untuk sensor peralatan navigasi kapal memudahkan proses integrasi dengan peralatan lainnya. Adapun sensorsensor navigasi kapal yang telah didukung dan digunakan sebagi input pada penelitian ini adalah GPS, Gyrocompass, Echosounder, Weather, dan Velocity [2]. Penelitian ini merujuk pada penelitian terkait yang telah dilakukan sebelumnya yaitu pembuatan data logger untuk monitoring suhu dalam suatu ruangan atau benda [3]. Kemudian data hasil pengukuran suhu direkam 
dalam suatu tabel. Penelitian lainnya adalah aplikasi data logger untuk komunikasi GPRS dengan web page sebagai sarana penampil dan penyimpanan data [4]. Penelitian mengenai penggenerasian data NMEA yang pernah dilakukan sebelumnya yaitu dengan mendesain hardware dan software sebagai pembuatan prosedur testing [5]. Terdapat pula alat yang telah berkembang di pasaran namun dengan harga yang cukup mahal [6], dibandingkan dengan sistem yang kemudian dapat dibuat dengan lebih sederhana dan bersifat low cost.

Penelitian ini mencoba untuk membuat suatu sistem data logger dengan komputer sebagai interface yang berfungsi untuk menginformasikan data dari sensorsensor navigasi kapal. Data logger yang dibuat bernilai low cost karena dibangun dengan mini prosesor berupa microcontroler ATMega328. Input data sensor berupa lima buah data NMEA yang diambil melalui mekanisme switching, sehingga sistem ini dapat mengakomodasi lima buah input sensor dan menghasilkan satu jalur output data.

Peralatan navigasi kapal maritim terdiri dari sensorsensor dan antarmuka penampil data. Sistem antarmuka navigasi kapal maritim yang ada pada saat ini merupakan sistem dengan fungsi yang masing-masing bekerja secara independent. Sebuah sensor memiliki sebuah sistem antarmuka penampil data tersendiri, dan tidak memiliki keterkaitan satu dengan lainnya, dari sisi fungsi maupun struktur jaringan data. Tampak pada Gambar 1, bahwa instalasi jaringan data setiap sensor navigasi dari suatu kapal maritim saling terpisah dan memiliki sistem penampil data tersendiri. Adapun penggabungan jalur data hanya terjadi pada saat terintegrasi dengan antarmuka perangkat radar dan ECDIS, atau perangkat pendukung lainnya.

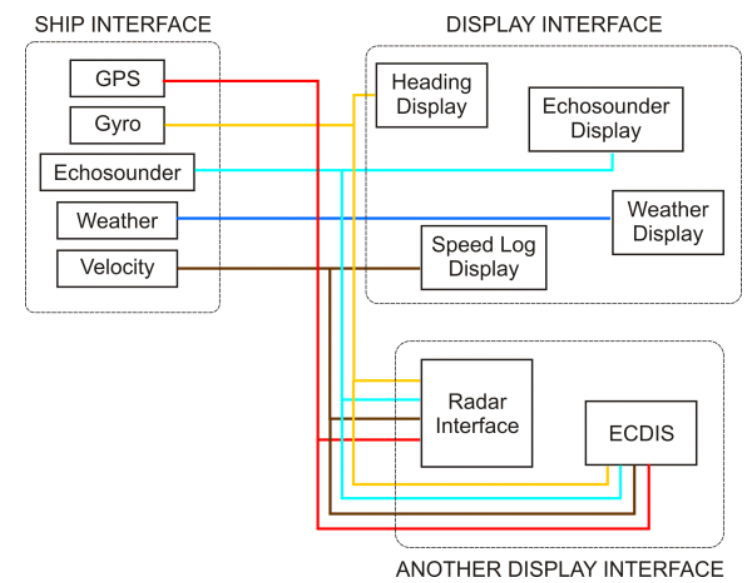

Gambar 1. Diagram Blok Peralatan Sensor Navigasi Kapal Maritim.

Salah satu bagian yang menjadi perhatian dari ide pembuatan data logger ini adalah kesamaan format komunikasi data yang digunakan dari masing-masing sensor, yaitu format komunikasi data NMEA [1]. Atas keseragaman format data yang digunakan pada setiap sensor navigasi, maka dapat dibuat suatu sistem untuk mentransmisikan data dari sensor-sensor navigasi melalui sebuah jalur yang sama tanpa mengubah struktur data yang dimiliki masing-masing sensor. Selain itu, tampilan informasi dari masing-masing sensor difokuskan pada satu antarmuka tampilan yang memuat keseluruhan informasi dari sensor-sensor.
Instalasi jaringan data yang sebelumnya terdiri dari lima jalur data pada Gambar 1, berubah menjadi lebih sederhana dengan sebuah jalur data untuk dapat menampilkan keseluruhan informasi dari sensor-sensor navigasi kapal, seperti yang diperlihatkan pada Gambar 2.

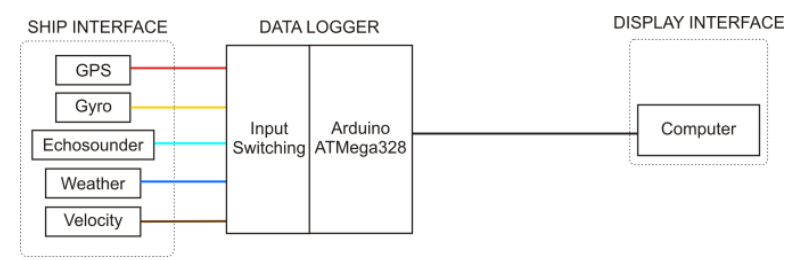

Gambar 2. Penggunaan Data Logger untuk Meringkas Tampilan Data Sensor Navigasi.

\section{Perancangan}

Sistem data logger terdiri atas dua modul utama yaitu rangkaian switching, yang berfungsi untuk mengatur urutan pengambilan data secara switching terhadap jalur data, dan modul microcontroller Arduino sebagai pengontrol switching dan pemroses data. Rangkaian pendukung terdiri dari modul converter tegangan data TTL ke level USB, dan rangkaian regulator tegangan untuk menyesuaikan tegangan power supply dengan tegangan kebutuhan setiap modul rangkaian. Gambar 3 berikut adalah diagram blok dari sistem data logger.

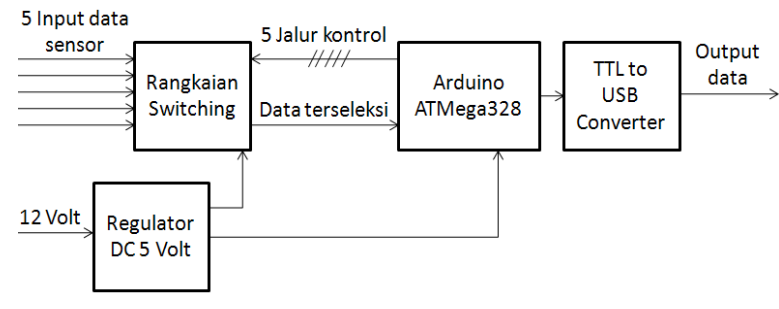

Gambar 3. Diagram Blok Sistem Data Logger.

Pembuatan sistem data logger ini didukung oleh beberapa komponen/modul yang terdiri dari: Arduino ATMega328 sebagai prosesor, rangkaian switching, converter level tegangan data serial TTL to USB, power supply, dan perangkat komputer sebagai display aplikasi. Microcontroler ATMega328 melakukan pengaturan pemilihan jalur data sensor. Kemudian data sensor disimpan sesuai dengan variabel yang telah disediakan. Satu paket data sensor disimpan dalam beberapa variabel sesuai dengan content informasi yang terkandung dalam data sensor tersebut seperti pada Gambar 4 berikut.

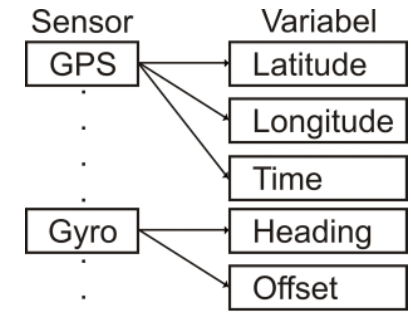

Gambar 4. Sebuah Sensor Memiliki Beberapa Variabel.

Microcontroller yang digunakan adalah ATMega328 dengan memanfaatkan modul Arduino 
Uno. Gambar 5 berikut ini adalah modul Arduino yang digunakan. Modul Arduino ini sudah dilengkapi dengan beberapa fitur yang mendukung pembuatan data logger pada penelitian ini.

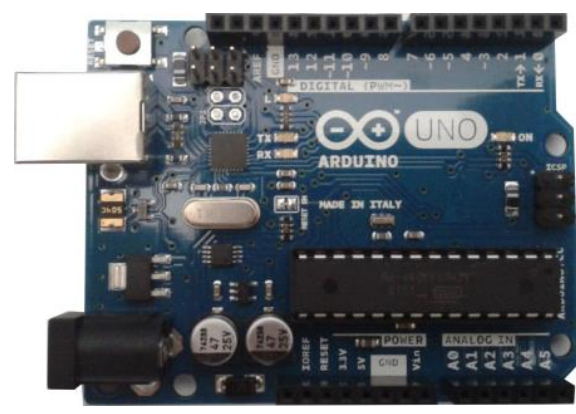

Gambar 5. Modul Arduino UNO ATMega328

Penelitian ini menggunakan lima buah data sensor dengan format data NMEA yaitu GPS, Gyrocompass, Echosounder, Weather, dan Velocity Sensor. Adapun fungsi sensor-sensor tersebut yaitu: GPS merupakan sensor untuk mengetahui data posisi suatu posisi origin objek, berdasarkan informasi kordinat beberapa satelit terhadap titik posisi objek (sensor), Gyrocompass berfungsi sebagai kompas yang memberikan nilai arah haluan kapal terhadap utara, sedangkan Echosounder sebagai sensor pengukur jarak kedalaman permukaan laut terhadap sensor yang berada di lambung bawah kapal, Weather Sensor memberikan informasi mengenai kecepatan angin sebagai indikator perubahan cuaca, dan Velocity Sensor sebagai alat pengukur kecepatan pergerakan kapal di atas permukaan air.

Mekanisme pengambilan data input adalah dengan melakukan switching untuk membuat suatu urutan pemilihan data input yang masuk ke dalam sistem. Microcontroller menangani seluruh proses pengambilan data dengan cara switching. Adapun proses switching tersebut dibantu dengan cara membuka dan menutup jalur data input menggunakan kombinasi rangkaian gerbang logika AND dan OR yang ditangani oleh IC 74LS08 [7] dan IC 74LS32 [8]. Desain rangkaian switching yang dibuat adalah seperti yang ditunjukkan pada Gambar 6.

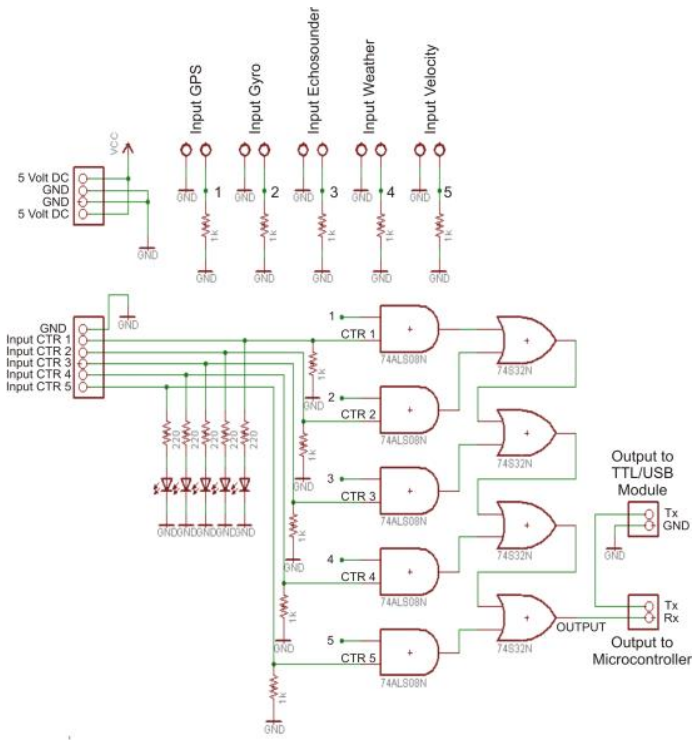

Gambar 6. Diagram Skematik Rangkaian Switching Lima Input dan Satu Output.
Pengaturan jalur input dilakukan dengan memberi input logika positif terhadap salah satu dari lima input pin pada IC AND yang terhubung, yaitu pada pin CTR1, CTR2, CTR3, CTR4 atau CTR5. Sementara itu data dari seluruh sensor dalam keadaan aktif. Apabila pin input CTR1 diberi level logika positif (high), sedangkan yang lainnya bernilai low, maka pada output akan muncul data $X_{1}$ (sensor GPS). Begitu pula seterusnya, perubahan perlakuan pada input lainnya akan menghasilkan data output yang berbeda. Tabel 1 berikut memberikan gambaran perubahan data output berdasarkan perlakuan input dengan logika yang berbeda-beda.

TABEL 1

NILAI LOGIKA KEBENARAN RANGKAIAN SWITCHING

\begin{tabular}{|c|c|c|c|c|c|}
\hline \multicolumn{5}{|c|}{ INPUT } & \multirow{2}{*}{ OUTPUT } \\
\cline { 1 - 5 } CTR1 & CTR2 & CTR3 & CTR4 & CTR5 & \\
\hline 1 & 0 & 0 & 0 & 0 & $\mathrm{X}_{1}$ \\
\hline 0 & 1 & 0 & 0 & 0 & $\mathrm{X}_{2}$ \\
\hline 0 & 0 & 1 & 0 & 0 & $\mathrm{X}_{3}$ \\
\hline 0 & 0 & 0 & 1 & 0 & $\mathrm{X}_{4}$ \\
\hline 0 & 0 & 0 & 0 & 1 & $\mathrm{X}_{5}$ \\
\hline
\end{tabular}

Keterangan:

$1=$ logika high

$\mathrm{Xn}=$ data digital sensor, dengan $\mathrm{n}$ :

$\mathrm{n}=1$; sensor $G P S$

$\mathrm{n}=2$; sensor Gyro

$\mathrm{n}=3$; sensor Echosounder

$\mathrm{n}=4$; sensor Weather

$\mathrm{n}=5$; sensor Velocity

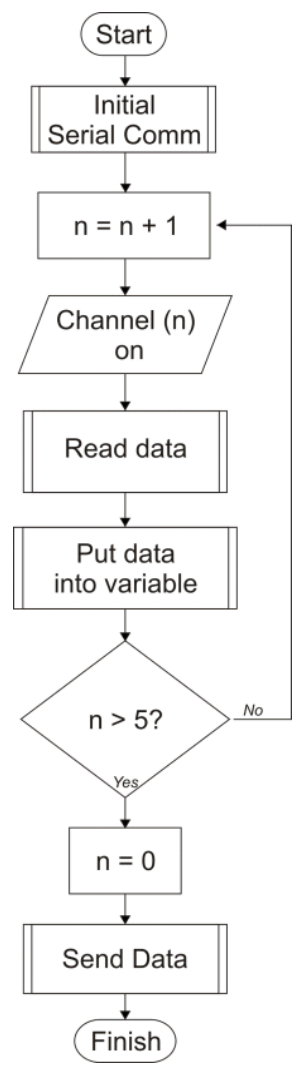

Gambar 7. Flow Chart Program Microcontroller. 
Desain software pada microcontroller dilakukan untuk membuat urutan perintah/instruksi dalam melakukan fungsi pengontrolan switching jalur input dan pengolahan data. Adapun alur perintah program yang dimasukkan dalam memori microcontroller ATMega 328 ditunjukkan pada Gambar 7 .

Urutan instruksi program yang bekerja pada microcontroller dapat dijelaskan pada beberapa poin berikut, yaitu:

a) Melakukan inisialisasi fungsi komunikasi data melalui port serial.

b) Operasi increament variabel $\mathrm{n}$ sebagai nilai pemilihan jalur input.

c) Aktifkan jalur input sensor yang ke-n.

d) Baca data NMEA sensor ke-n.

e) Masukkan data sensor ke dalam variabel-variabel.

f) Apakah nilai var $>5$ ? Jika tidak, ulangi ke langkah b). Jika ya, teruskan ke langkah g).

g) Berikan nilai $\mathrm{n}=0$.

h) Kirim data melalui port serial.

i) Instruksi selesai.

\section{HaSIl ANALISIS}

Data sensor yang digunakan pada penelitian ini terdiri dari lima buah data sensor dengan format standar NMEA. Masing-masing sensor memiliki identitas header yang berbeda dan unik. Data NMEA untuk sensor GPS diawali dengan header \$GPGLL, data sudut heading diawali dengan \$HCHDG, data Echosounder diawali dengan \$SDDBT, Wheather dengan \$WIMWD, dan data Velocity dengan \$VWVLM.

Pengujian dilakukan terhadap tiga bagian dari sistem yaitu; pengujian data input sensor secara simulasi (menggunakan aplikasi NMEA Generator), kemudian pengujian terhadap proses seleksi data pada sistem switching, dan pengujian ekstraksi data di software aplikasi penampil data.

Pengujian data input dilakukan secara simulasi menggunakan aplikasi NMEA Generator sebagai penggenerasi data setiap sensor, dan hyperterminal sebagai penampil data yang diterima. Diagram pengujian ditunjukkan pada Gambar 8 .

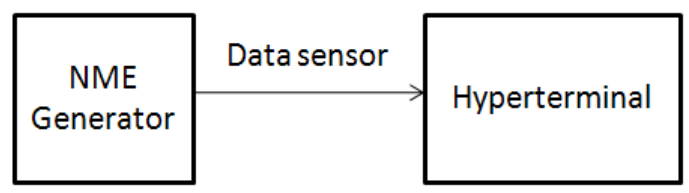

Gambar 8. Pengujian Data Input.

Hasil penampilan data menggunakan hyperterminal terhadap seluruh sensor, ditunjukkan pada Gambar 9.

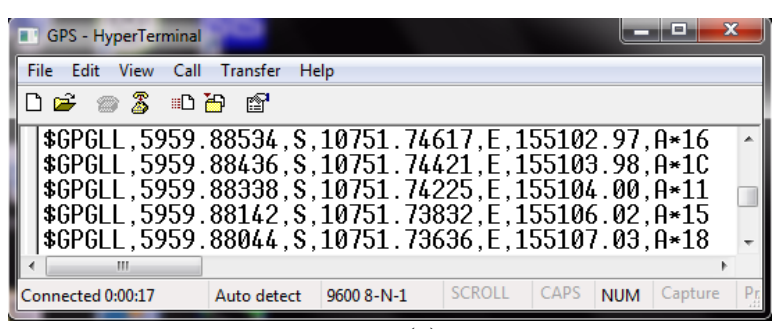

(a)

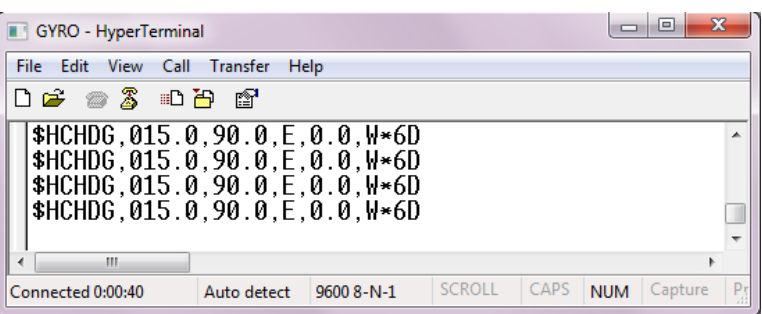

(b)

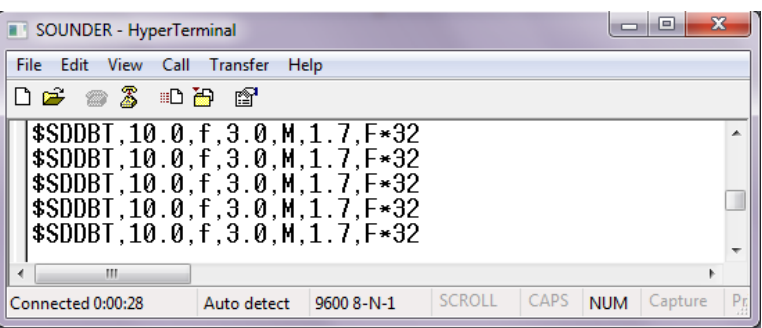

(c)

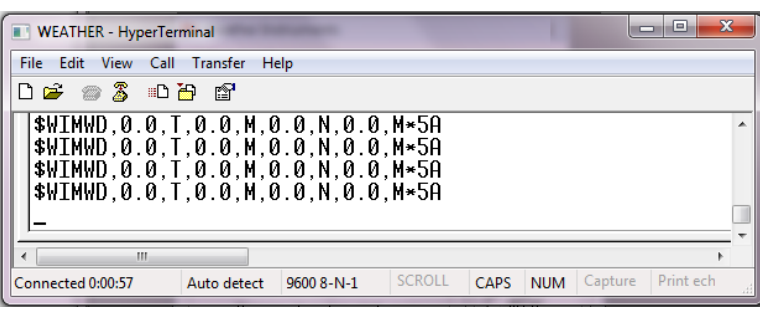

(d)

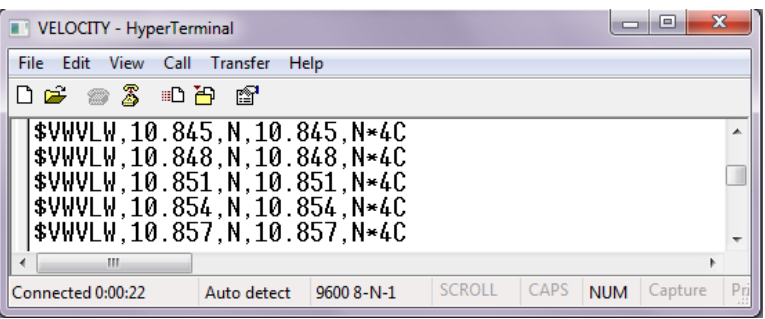

(e)

Gambar 9. Data Input Terbaca di Hyperterminal, (a) Data GPS, (b) Data Gyro, (c) Data Echosounder, (d) Data Weather Sensor, dan (e) Data Velocity.

Pengujian terhadap data input simulasi NMEA Generator yang dilakukan pada rentang waktu 1 menit terhadap lima data sensor yaitu; GPS, Gyro, Echosounder, Weather Sensor dan Velocity Sensor, selama 60 detik memperlihatkan bahwa seluruh data yang diberikan sebagai input dari data logger, dapat terbaca dari sisi penerima dengan tingkat akurasi 100\%, seperti ditunjukkan pada Tabel 2.

TABEL 2

PENGUJian DATA INPUT SENSOR DALAM 60 DETIK

\begin{tabular}{|l|c|c|c|c|}
\hline Sensor & $\begin{array}{c}\text { Jumlah } \\
\text { data } \text { input }\end{array}$ & $\begin{array}{c}\text { Jumlah } \\
\text { data } \\
\text { diterima }\end{array}$ & $\begin{array}{c}\text { Jumlah } \\
\text { data } \\
\text { cacat }\end{array}$ & Akurasi \\
\hline GPS & 59 & 59 & 0 & 1 \\
\hline Gyro & 59 & 59 & 0 & 1 \\
\hline Echosunder & 59 & 59 & 0 & 1 \\
\hline Weather & 59 & 59 & 0 & 1 \\
\hline Velocity & 59 & 59 & 0 & 1 \\
\hline
\end{tabular}

Seluruh proses pengolahan data dilakukan dengan microcontroller dibantu dengan rangkain switching untuk mengatur mekanisme pemilihan jalur sensor. Adapun rancangan rangkaian switching yang telah diaplikasikan dalam bentuk jalur pada PCB ditunjukkan pada Gambar 10. 


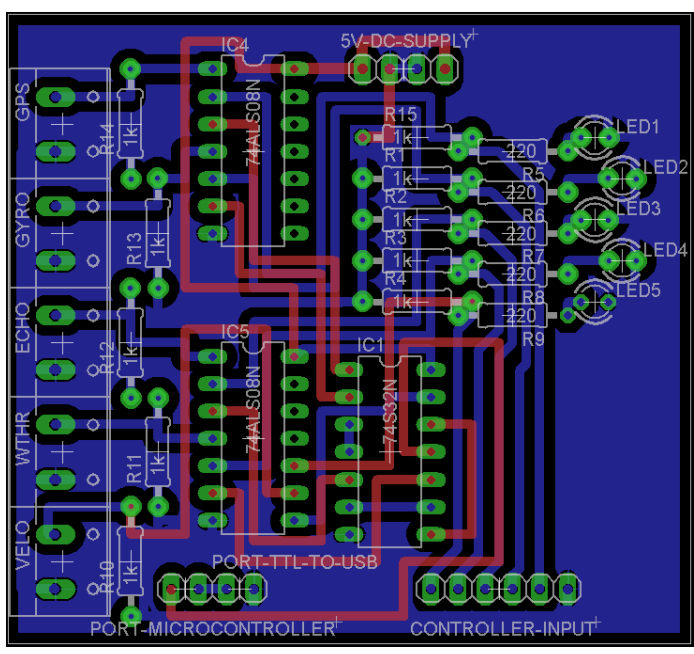

Gambar 10. Desain Double Layered PCB Rangkaian Switching.

Selanjutnya pada Gambar 11 adalah tata letak komponen pada double layered PCB yang telah dicetak sesuai dengan hasil perancangan. Komponen yang diperlukan untuk melengkapi rangkain ini adalah: 5 buah resistor $220 \mathrm{ohm}, 10$ buah resistor $1 \mathrm{k} 2 \mathrm{ohm}, 2 \mathrm{IC}$ 74LS08, 1 IC 74LS32, 4 buah LED, 5 buah terminal blok, serta 2 buah pin header 4 pin dan 1 buah pin header 6 pin.

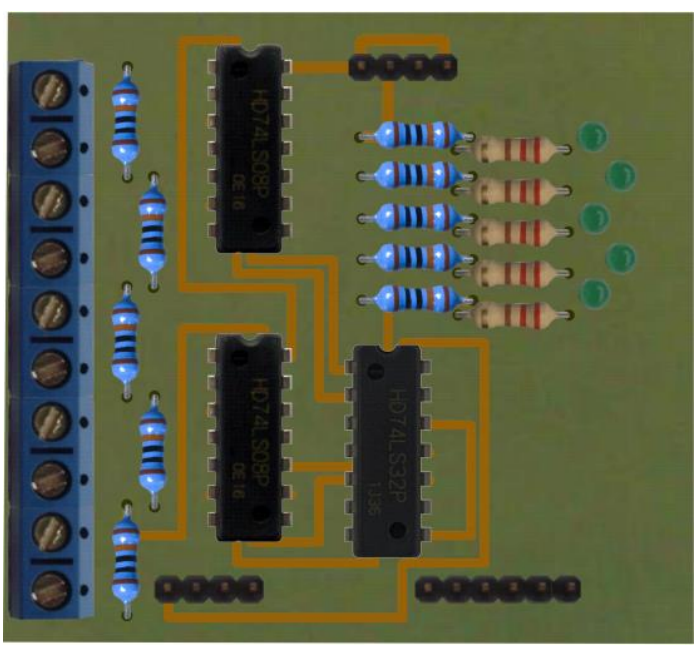

Gambar 11. Tata Letak Komponen di Atas PCB.

Diagram instalasi dari sistem data logger digambarkan pada Gambar 12. Pada sistem ini diperlukan power supply dengan tegangan DC sebesar 12 Volt. Tegangan power supply kemudian diturunkan menjadi 5 Volt menggunakan modul regulator tegangan DC. Jalur input tersedia sejumlah 5 pasang jalur data dengan ground, sedangkan jalur output tersedia 1 jalur berpasangan dengan ground dan terhubung dengan modul converter level tegangan serial TTL to USB.

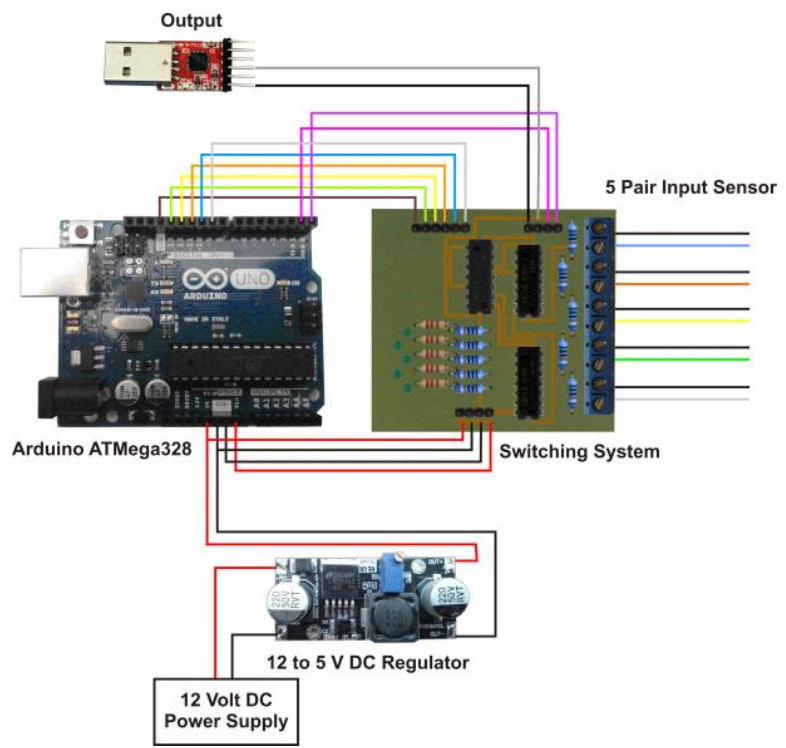

Gambar 12. Diagram Jalur Instalasi Sistem Data Logger.

Data output disusun dengan format yang telah ditentukan, disesuaikan dengan aplikasi software yang dibuat. Pada penelitian ini, seluruh data sensor yang tersimpan dalam variabel program dipisahkan dengan karakter "; ". Bentuk utuh data output adalah seperti pada Gambar 13 berikut ini.

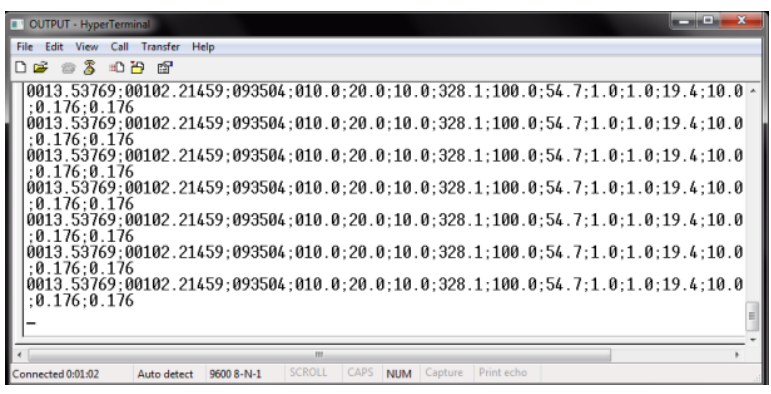

Gambar 13. Data Output.

Apabila data output ditampilkan pada aplikasi software, maka akan data akan tersusun pada setiap panel informasi masing-masing sensor seperti ditunjukkan pada Gambar 14.

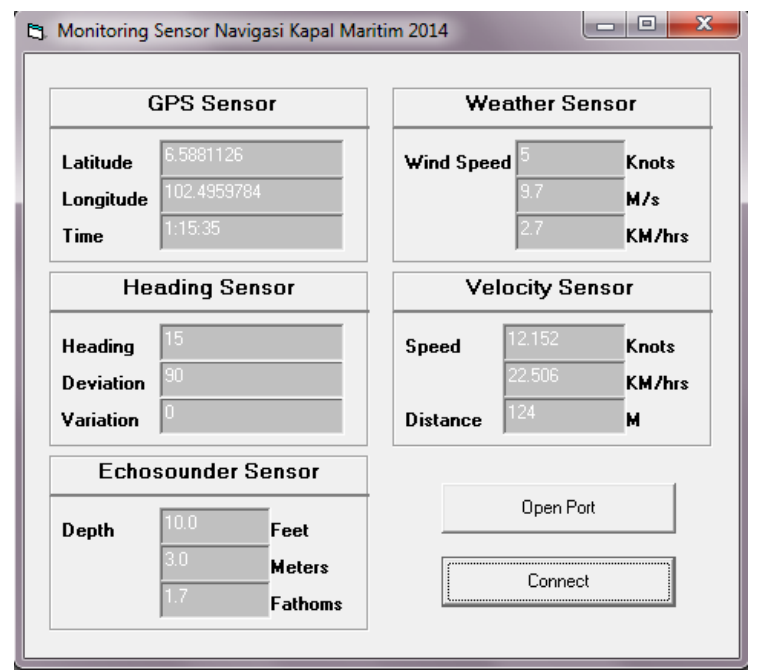

Gambar 14. Display dari Data Logger. 
Pengujian di sisi penerima/receiver dilakukan untuk mengamati hasil ekstraksi data yang diterima dan ditampilkan pada software aplikasi untuk display.

TABEL 3

PENGUJIAN DATA Di SiSi RECEIVER

\begin{tabular}{|l|c|c|c|}
\hline \multicolumn{1}{|c|}{ Sensor } & $\begin{array}{c}\text { Jumlah data } \\
\text { input }\end{array}$ & $\begin{array}{c}\text { Jumlah data } \\
\text { display }\end{array}$ & Akurasi \\
\hline GPS & 100 & 96 & 0,96 \\
\hline Gyro & 100 & 97 & 0,97 \\
\hline Echosunder & 100 & 98 & 0,98 \\
\hline Weather & 100 & 97 & 0,97 \\
\hline Velocity & 100 & 98 & 0,98 \\
\hline
\end{tabular}

Berdasarkan hasil pengujian yang ditunjukkan pada Tabel 3, bahwa jumlah data yang dapat diekstraksi pada software aplikasi display berbeda-beda keakurasiannya. Hal tersebut bisa saja terjadi dikarenakan masingmasing sensor memiliki panjang data yang berbeda satu dengan lainnya, dan juga dipengaruhi kecepatan kemampuan software pada saat melakukan proses ekstraksi data.

Data logger lima input data sensor navigasi dengan format standar NMEA merupakan sistem pengolah data yang mampu menampung lima buah data sensor dari sumber yang berbeda-beda yaitu data sensor GPS, Gyrocompass, Echosounder, Weather dan Velocity. Alat ini menampilkan informasi yang real time kepada user mengenai informasi navigasi yang berguna dalam operasional kapal di laut. Selain itu juga output data logger ini dapat dimanfaatkan lebih lanjut untuk peralatan lain yang membutuhkan informasi dari data sensor-sensor navigasi kapal, dengan beberapa penyesuaian setting data.

\section{KESIMPULAN}

Penelitian sistem data logger lima channel input sensor navigasi kapal maritim menghasilkan kesimpulan:

a. Bahwa beberapa data sensor yang berasal dari sumber yang berbeda dapat dihimpun dalam suatu sistem interface dengan memanfaatkan kondisi format standar universal suatu komunikasi data.

b. Software aplikasi display data logger ini dapat menampilkan informasi sensor-sensor navigasi kapal dengan tingkat akurasi 96\% untuk sensor GPS, 97\% untuk Gyro, 98\% untuk Echosounder, 97\% untuk Weather, dan $98 \%$ untuk sensor Velocity.

c. Penelitian ini memberikan sumbangan bahwa suatu data logger dapat dibangun dengan komponen sistem yang jauh lebih murah dari produk yang beredar di pasaran, dan dapat dikostumisasi untuk keperluan integrasi dengan perangkat lainnya yang mendukung.

\section{Daftar Pustaka}

[1] (2014). NMEA 0183 standard. [Online]. Available: http://www.nmea.org/content/nmea_standards/nmea_0183_v_41 0.asp

[2] (2014). Peralatan-peralatan navigasi di kapal. [Online]. Available: http://www.maritimeworld.web.id/2014/07/apa- yangdimaksud-dengan-radar-dan-fungsi -radar-kapal.html

[3] N. L. Marpaung dan E. Ervianto, "Data logger sensor suhu berbasis mikrokontroler atmega 8535 dengan PC sebagai tampilan”, Jurnal Ilmiah Elite Elektro, vol. 3, no. 1, hal. 37-42, 2012.

[4] D. Munandar, O. Mahendra, D. Syamsi, "Data logger application development using microcontroller atmega 128 for a web-based gprs communication", The 6th International Conference on Information \& Communication Technology and Systems, vol. 4, 2010, hal. 27-32.

[5] V. Sinivee, "Simple yet efficient NMEA sentence generator for testing GPS reception firmware and hardware", in Novel Algorithms and Techniques in Telecommunications and Networking, T. Sobh, K. Elleithy, and A. Mahmood, Ed. Dordrecht: Springer Science+Business Media B.V., 2010, pp. 207-210

[6] (2014). Vessel data logging to SD memory now available for seasmart network adapters. [Online]. Available: http://www.seasmart.net/marine-wireless-networking-press.html

[7] (2014). SN5408, SN54LS08, SN54S08, SN7408, SN74LS08, SN74S08, quadruple 2-input positive-and gates. [Online]. Available: www.ti.com/lit/gpn/sn54s08

[8] (2014). SN5432, SN54LS32, SN54S32, SN7432, SN74LS32, SN74S32, quadruple 2-input positive-or gates. [Online]. Available: www.ti.com/lit/ds/symlink/ sn74ls32.pdf 